\title{
Identification of Severity Factors and Risk Areas of Southern Expressway Accidents
}

\author{
S.D.D.R. Kumara and C.K. Walgampaya
}

\begin{abstract}
Introduction of the Expressway concept to the road network of the Country is undoubtedly a development which has made transportation and commuting easy and time saving. "Southern Expressway Project", commenced in 2003, is the first national highway in Sri Lanka. However, the number of accidents and the severity of the accidents in the Southern Expressway reflect an increase over the years. This study attempted to analyse the severity factors of accidents in expressways. The study utilized secondary data collected by the Southern Expressway Operation, Maintenance and Management Division (EOMMD) during the period 2011 to 2018. The Preliminary Analysis was followed by Hotspot Analysis under quantitative techniques and Photographic survey along with live driving experience methods under qualitative techniques. Study also collected information from the officers of the Expressway Management via discussions in order to triangulate and validate the results. Accident prone locations for severe and minor level accidents were identified along with the significant reasons for accidents. Among the numerous reasons affecting the severity of the accidents, the behavioural factors such as drunk driving, fatigue and driving speed were significant. Animal crossing across the highway was also a critical factor of accident severity levels. Roadside landscape and structural elements were also found to be important factors to be considered for the national policy on safety management of expressways in Sri Lanka. The study also proposed measures to be taken to minimize the severity level of accidents.
\end{abstract}

Keywords: Expressway accidents, Accident severity, Hotspot analysis

\section{Introduction}

World Health Organization report on "Global Health Safety 2018" revealed that road traffic injuries claim more than 1.35 million lives each year and have a huge impact on health and development of the human society. Moreover, the report states that approximately $3 \%-5 \%$ cost on GDP in low and middle income countries is due to road accidents [1]. Road traffic accidents had been the $8^{\text {th }}$ leading cause of death among all ages in 2016 while being the number one cause of death for children and young adults between the ages $5-29$ years. It is noted that fatality due to accidents in lowincome countries is three times higher than in the high- income countries. Also, deaths due to road traffic accidents have shown a rapid increase over the years worldwide.

In this context, Sri Lanka is no exception. Over the years, road traffic accidents as well as property damages, personal injuries and deaths due to road traffic accidents have rapidly increased. Statistics of the Sri Lanka Police Department reflect that the total number of deaths due to road accidents from 2011 to 2017 has increased from 2,677 to 3,147. Introducing the highway in 2011, Sri Lanka had made a revolution in the country's traditional transportation system.

While contributing towards the economic development of the country by facilitating an effective commuting mechanism, the expressway system contributes towards increased numbers of road accidents in Sri Lanka.

\section{Literature Survey}

\subsection{Contemporary Literature}

Numerous studies have been conducted on road traffic accidents all over the world while having comparatively lesser investigations on expressway accidents. Most of the research conducted on road traffic accidents are focused towards finding the patterns and determinants of road traffic accidents and cost of accident related deaths or morbidity. On the other hand,

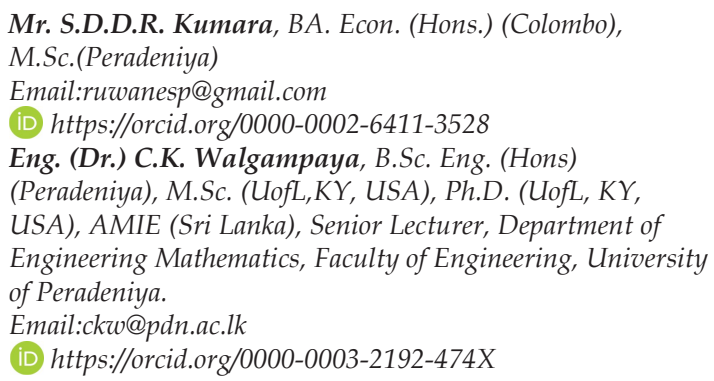


accidents on expressways have become an important factor of mortality patterns all over the world. In the Sri Lankan context, highway related accidents, deaths, property damage and other losses have become serious concerns during the last ten years.

Most of the research on expressways has been directed towards figuring out the factors associated with highway accidents whilst a few of such research identify the factors associated with severity of expressway accidents. According to the Haddon Matrix developed by William Haddon in 1970's, factors affecting road injuries can be classified into three categories: human, vehicle and environmental factors [2]. A considerable amount of literature published on expressway related accidents are being based on this principle.

Human factors refer to both physical and mental behaviour of the drivers. Attempting to review the human factors causing road traffic crashes, Petridou et al. identify that three (03) out of five (05) accidents were due to driver related behavioural factors and the respective factors contributed to the occurrence of $95 \%$ of total accidents [3]. Study on road traffic injuries in Thailand using Hospital-Based data, Highway data and Police data identified a number of behavioural risks i.e., drunk driving, not using seat belts and speeding [4].

A case control study by Hijar et al, [5] which set out to determine the risk factors related to the driver, vehicle and environment found that following factors are to be risks for injuries: being under the age of 25 compared to the age of 25 or over; being unemployed compared to those who have jobs; and alcohol intake. Further, the study reveals that travelling at night than during daylight hours; during a weekday instead of during weekend; and travelling under adverse climatological conditions have a greater risk [5]. This study found no association to the vehicle related variables.

Åkerstedt et al. examined the risk of expressways in terms of night driving and seasonal impact using police reported accidents on five major highways in Sweden [6]. This study is focused on accidents where alcohol intoxication was controlled. The study also found that, compared to driving in daylight, the relative risk of having an injury was five times at night. Furthermore, the study revealed that sleepiness, monotony and poor visibility as causes of increasing the night time risk. When considering the behavioural factors, the authors suspect that driving behaviour might be different at night, i.e., less traffic at night may encourage the driver to increase speed and night driving could attract careless driving. Study by Åkerstedt et al. confirmed that night driving on highways increases the risk of being involved with an accident for both genders [7].

Controlling for age, the aforesaid study computed the relative risk associated with gender when considering the female gender as a reference group. For the 18-24 age group the males had a lower risk than females whilst in the 25-44 age group males were at higher risk. Also, in the $45+$ age group males were at higher risk than females both at night and early morning.

In 2016, Boni et al. published a paper in which they aimed to investigate the causes of road accidents at Dhaka to Aricha Highway [8]. Study involved data collected using both questionnaire survey and photographic survey. Photographic survey findings showed that behavioural factors such as reckless driving, not wearing seat belts and competition between drivers were major risk elements. On the other hand, the study highlighted the vehicle related risk factors, i.e., failure of brakes, poor quality steering and tires, insufficient headlights, failing to adjust the mirror while driving etc.

While quantifiable researches have been attempted to investigate the factors associated with expressway accidents all over the world, only a few academic efforts have been made to find out the factors of severity of highway accidents. In order to find the factors which are directly associated with severity of highway accidents, a variety of methodological techniques can be applied [9].

DeOña et al. analysed the factors associated with severity of highway accidents on rural highways in Granada (Spain) [10]. The study used both Cluster and Bayesian Networks (BN) analysis techniques in order to identify the main factors that contribute to crash severity. Study results found that a set of variables (month, time, day, number of injuries, accident type, cause, age, gender, pavement width, shoulder type, pavement markings and sight distance) had exhibited direct dependence relationships with severity. On the other hand, no direct link was observed between severity and atmospheric factors. Another study examined the severity of road traffic accidents in Kenya using multivariate Logit Regression analysis [11]. Study findings reconfirmed that rainy weather and night time driving were risk factors against severe injuries. 
In the Sri Lankan context, there are fewer studies on severity of expressway accidents while considerable attempts have been made with regard to identification of factors causing road accidents [12]. Analysis on the Trends in Fatal Accidents of Vulnerable Road Users in Sri Lanka has attempted to analyse and describe vulnerable road users with respect to many parameters [13]. The study focused on trends in accident fatality rates, identifying vulnerable road users and vehicle users in terms of deaths, causes for accidents and policy measures to decrease fatalities due to road traffic accidents. According to findings of the study, pedestrian, pedal cyclist and motorcycle users are identified as the most vulnerable road users for fatal accidents in Sri Lanka.

According to the numerous studies, age of the driver (age between 18 - 30), drunk driving and speed are found to be the most influential human related factors for the severity of road traffic accidents in Sri Lanka [14]. Another analysis to identify factors of accident severity confirmed that "type of vehicle" and "age" are influential variables for accident severity [15]. Severity factors on road accidents, included road condition with wet and slippery road surface, bad weather condition (rainy and the fog/mist), light condition with daylight, no light at night and improper light at night. Dusk and dawn were also found to be significantly affected [12]. However, some of the studies conclude that there is no direct relationship between rainfall intensity and the number of accidents occurred [16].

Prevention of accident occurrence is a challenge for any country or respective intuitional bodies like the World Health Organization (WHO). However, identification of accident prone locations creates a space to prevent future accidents. Identifying hotspots help traffic authorities to reduce crashes by finding appropriate solutions [17]. According to the studies, it is understood that numerical analyse to determine accident risk locations (hotspots) have been carried out all over the world using different tools and techniques [18]. Geographical Information System (GIS) also can be utilized to visualize the identified hotspots to further strengthen the validity of the results [19].

On a study to identify road traffic accident hotspots in the capital city of Vietnam (Hanoi) an attempt has been made to identify accident hotspots in Hanoi by day time intervals and seasons [20]. Another research attempt has been carried out to identify the traffic accident hotspots using Geographical Information System (GIS) in Moines city, Iowa State, USA [17]. Although there were 24660 locations under three severity levels: fatalities, injuries, and property damage, this study considered only the injury-type accidents for the spatial analysis. Truong et al. in 2011 applied GIS based methodology to identify pedestrian-vehicle crash hot spots and unsafe bus stops in Adelaide, the capital city of South Australia [18]. This research used all pedestrian-vehicle crash data for 13 years from year 1996 to 2008 . Analysis created a pedestrian-vehicle crash hot spots map and ranked unsafe bus stops in the study area.

Analysis of accidents hotspots in expressways is relatively different from usual road accident hotspots as expressways have different conditions and factors with regard to accident occurring. But it is possible to use similar techniques for special analysis. A study was carried out to identify spatial pattern of hotspots in North South Expressway (NSE) from Sungai Petani to Bukit Lanjan during 2011 to 2014 period in Malaysia [19]. Two spatial analysis techniques, Nearest Neighbourhood Hierarchical (NNH) Clustering and Spatial Temporal Clustering, were applied for the study.

In the Sri Lankan context, there are less number of analysis on hotspots in expressways. The reason for the lack of studies could be due to the shorter experience in expressways as a country. However, an analysis of accidents in the Southern Expressway had been carried out in order to identify accident - prone locations, possible causes for accidents and to estimate the accident rate based on vehicle travelled kilometres [21]. Study identified nine accidentprone locations and the factors which cause highway accidents: rainy weather, sleepiness due to fatigue, longer travel distance. However, the study did not consider the factors which affect the severity of highway accidents in the Southern Expressway.

Another study to identify the impact of road landscape to driving behaviour in Southern Highway was carried out [22]. Study identified two locations as "black-spots" and analysed the particular two points using three spatial characteristics: Solidity \& degree of enclosure; differentiation of forms and proportion of the space with respect to the observer. The study concluded that minimum solid and void spaces in both points creates a monotonous/fatigue driving experience. Less differentiation of 
landscape forms reduces driving performance. Thus the road side landscape plays a critical role in driving behaviour in expressways.

\subsection{Concepts}

\section{Haddon Matrix}

Haddon Matrix concept was developed by Willam Haddon, a public health physician in the 1970 's. This is one of the commonly used scientific methods or a paradigm used to study injury prevention (Table 1). He stated in one of his publications, "This framework originally involved classifying factors that contributed to motor vehicle injuries into three categorieshuman, vehicle/ equipment, and environmentand three time periods: before, during, or after the crash" [2].

Table 1 - A Typical Haddon Matrix

\begin{tabular}{|c|c|c|c|}
\hline Phase & $\begin{array}{l}\text { Human } \\
\text { Factors }\end{array}$ & $\begin{array}{l}\text { Vehicles and } \\
\text { Equipment } \\
\text { Factors }\end{array}$ & $\begin{array}{c}\text { Environmental } \\
\text { Factors }\end{array}$ \\
\hline $\begin{array}{l}\text { Pre- } \\
\text { crash }\end{array}$ & $\begin{array}{l}\text { - Information } \\
\text { - Attitude } \\
\text { - Impairment } \\
\text { - Police } \\
\text { Enforcement }\end{array}$ & $\begin{array}{l}\text { - Road } \\
\text { Worthiness } \\
\text { - Lighting } \\
\text { - Braking } \\
\text { - Speed } \\
\quad \text { Management }\end{array}$ & $\begin{array}{l}\text { - Road design } \\
\text { and layout } \\
\text { - Speed limit } \\
\text { - Pedestrian } \\
\text { facilities }\end{array}$ \\
\hline Crash & \begin{tabular}{|l|} 
- Use of \\
restraints \\
- Impairments
\end{tabular} & $\begin{array}{l}\text { - Occupant } \\
\text { restraints } \\
\text { - Other safety } \\
\text { devices } \\
\text { - Crash } \\
\text { protective } \\
\text { design }\end{array}$ & $\begin{array}{l}\text { - Crash- } \\
\text { protective } \\
\text { roadside objects }\end{array}$ \\
\hline $\begin{array}{l}\text { Post } \\
\text { Crash }\end{array}$ & $\begin{array}{l}\text { - First-aid skills } \\
\text { - Access to } \\
\text { medics }\end{array}$ & $\begin{array}{l}\text { - Ease of access } \\
\text { - Fire risk }\end{array}$ & $\begin{array}{l}\text { - Rescue facilities } \\
\text { - Congestion }\end{array}$ \\
\hline
\end{tabular}

The matrix introduced ten (10) items which are called "Haddon Strategies", as possible ways to prevent injuries. Above ten possible injury prevention strategies were classified under three major components as Pre event, Event and Post event. The classification is as follows:

\section{- Pre-event}

i. Prevent the existence of the agent.

ii. Prevent the release of the agent.

iii. Separate the agent from the host.

iv. Provide protection for the host.

\section{- Event}

v. Minimize the amount of agent present

vi. Control the pattern of release of the agent to minimize damage vii. Control the interaction between the agent and host to minimize damage

viii. Increase the resilience of the host.

\section{- Post-event}

ix. Provide a rapid treatment response for host

x. Provide treatment and rehabilitation for the host

\section{Hotspot Analysis}

Hotspot analysis is a spatial analysis and a mapping technique which can be applied to identify statically significant clusters of spatial phenomena. This defines clusters of given features with values significantly higher or lower than the overall mean of the study area. In order to identify statistically significant areas necessary for policy actions, the output maps created using the Hotspot Analysis are very beneficial and effective tools.

Heat Map is also a common tool which can be applied for spatial analysis which shows the density of occurrence. In order to create a heat map, point data is analysed and the map shows where the clusters of the respective data set exists. However, it does not explain whether the clusters are statistically significant or not. The results of these maps are said to be subjective as they depend on the interpreter.

However, in Hotspot Analysis, statistically significant test statistics are applied to define areas of high and low occurrences. Therefore, visualization of the clusters is less subjective and more reliable. Numerous methods can be utilized for the hotspot analysis based on the research purpose and features of the data set such as: Spatial Temporal Scan Statistics, Spatial point pattern analysis, Spatio-Temporal density clustering and local spatial autocorrelation statistics.

The Local Spatial Autocorrelation statistics mainly study the relationship among the same property or magnitude from different events in an area. It uses statistical measurements to quantify the local degree of correlation between objects. To investigate the spatial variation and the spatial associations, it is necessary to rely on local measures such as Getis-Ord $\mathrm{Gi}^{*}$ statistics [23].

One of the approaches in Local Spatial Autocorrelation statistics is called Getis-Ord Gi* statistics or in general, $\mathrm{G}$ statistics. This statistic measures the degree of association that results from the concentration of weighted points 
(or area represented by a weighted point) and all other weighted points included within a radius of distance $d$ from the original weighted point.

$G$ statistics makes decisions about statistical hypotheses $H_{0}$ (Null hypothesis) and $H_{1}$ (Alternative hypothesis) as mentioned below.

$H_{0}$ : the values of the attribute are randomly distributed in the study area (i.e. there is no spatial clustering of feature values)

$\mathrm{H}_{1}$ : the attribute exhibits spatial clustering in the study area

Functional notation of G Statistics is shown as below.

$$
G_{i}^{*}=\frac{\sum_{j=1}^{n} w_{i, j} x_{j}-\bar{X} \sum_{j=1}^{n} w_{i, j}}{s \sqrt{\frac{\left[n \sum_{j=1}^{n} w_{i, j}^{2}-\left(\sum_{j=1}^{n} w_{i, j}\right)^{2}\right]}{n-1}}}
$$

Where $x_{\mathrm{j}}$ is the attribute value for feature $j, w_{i, j}$ is the spatial weight between feature $i$ and $j, n$ is equal to the total number of features. Also,

$\bar{X}=\frac{\sum_{j=1}^{n} x_{j}}{n}$

$S=\sqrt{\frac{\sum_{j=1}^{n} x_{j}^{2}}{n}}-(\bar{X})^{2}$

The G statistic also follows a normal distribution and statistical decision of the G Statistics is based on the p-value related to the respective $Z$ value. Decision rule of clustering is as follows:

If, p-value > a: we cannot reject the null hypothesis; the data point (selected feature) does not provide evidence of spatial clustering in the study area.

If, p-value < a and z-score $>0$ : we can reject the null hypothesis i.e. feature exhibits spatial clustering with high values for the attribute (hot spots).

If, $\mathrm{p}$-value < a and z-score < 0: we can reject the null hypothesis i.e. feature exhibits spatial clustering with low values for the attribute (cool spots). Where, a represents the significance level of the test, it can vary according to the requirement, usually $95 \%$ confidence level gives 0.05 for $a$.

In ArcGIS, the Hot Spot Analysis tool uses Getis-Ord General $G$ statistics to find the High/Low Clusters in the spatial datasets. At the beginning of the process, this tool calculates the Getis-Ord Gi* (pronounced G-i-star) statistic for each feature in a dataset. The resultant $\mathrm{z}$ scores and p-values measure the degree of clustering for each feature.

This tool works by looking at each feature within the context of neighbouring features. Although a feature with higher value looks very interesting, it may not be a statistically significant hot spot.

In order to be a statistically significant hot spot, the feature should have a higher value itself and also the feature should be surrounded by features with higher values. Based on that theory, Arc Gis tool "hotspot" calculates z values and related $p$-values with a selected significance level.

Z-scores and related $p$-values of the analysis identify whether the features with either high or low value cluster are spatially statistically significant or not. Positive z-score which is statistically significant refers to hot spots while negative z-score represents cold spots. Finally, the graphical representation of the hotspots analysis is done by creating output maps with significant hot and cold spots.

\section{Data and Methodology}

\subsection{Data}

This study considers secondary data collected from the Southern Expressway Operation Maintenance and Management Division (EOMMD), RDA for the past eight (08) years, covering the period from 2011 to 2018. The study includes only the data from Kottawa to Godagama interchange as the extension beyond Godagama was opened subsequent to collection of data for the research. Total number of accidents recorded during this period was 5239 and the study examined that 5239 observations for the analysis procedure. Although the EOMMD collected information on a number of aspects, following variables were extracted and rearranged where necessary for the purposes of the study (Table 2).

\section{Table 2 - Definition of Variables Used in the} Study

\begin{tabular}{|l|l|}
\hline Variable Name & Coding number / Notes \\
\hline \multirow{3}{*}{ Type of the accident } & Fatal \\
& $\begin{array}{l}\text { Grievous } \\
\text { Non- Grievous } \\
\text { Property Damage }\end{array}$ \\
\hline Accident year & 2011 - 2018 \\
\hline Accident months & January - December \\
\hline Accident days & Monday to Sunday \\
\hline Accident occurred on & 0. Weekday. \\
\hline
\end{tabular}




\begin{tabular}{|c|c|}
\hline weekday or weekend & 1. Weekend \\
\hline $\begin{array}{l}\text { Accident informed time } \\
\text { (exact) }\end{array}$ & 24hr Clock \\
\hline $\begin{array}{l}\text { Accident informed time } \\
\text { (categories) }\end{array}$ & $\begin{array}{l}\text { Day Off Peak } \\
\text { Day Peak } \\
\text { Night }\end{array}$ \\
\hline $\begin{array}{l}\text { Direction of the occurred } \\
\text { accident }\end{array}$ & $\begin{array}{l}\text { LHS - Kottawa to Matara } \\
\text { RHS - Matara to Kottawa } \\
\text { Rest Area }\end{array}$ \\
\hline $\begin{array}{l}\text { Number of injured } \\
\text { persons }\end{array}$ & No. \\
\hline $\begin{array}{l}\text { Number of deaths due to } \\
\text { accident }\end{array}$ & No. \\
\hline $\begin{array}{l}\text { Number of vehicles } \\
\text { involved in the accident }\end{array}$ & No. \\
\hline $\begin{array}{l}\text { Immediate reason for the } \\
\text { accident }\end{array}$ & $\begin{array}{l}\text { Categorical variable with } \\
17 \text { categories }\end{array}$ \\
\hline $\begin{array}{l}\text { If the accident occurred } \\
\text { due to animal crossing, } \\
\text { type of the animal. }\end{array}$ & Name \\
\hline $\begin{array}{l}\text { Average speed of the } \\
\text { accident vehicle/vehicles }\end{array}$ & $\mathrm{km} / \mathrm{hr}$ \\
\hline $\begin{array}{l}\text { Road surface condition } \\
\text { during the period of } \\
\text { accident }\end{array}$ & $\begin{array}{l}\text { Dry } \\
\text { Wet }\end{array}$ \\
\hline $\begin{array}{l}\text { Weather condition during } \\
\text { the period of accident }\end{array}$ & $\begin{array}{l}\text { Clear } \\
\text { Misty } \\
\text { Cloudy/Rainy }\end{array}$ \\
\hline $\begin{array}{l}\text { Light condition during } \\
\text { the period of accident }\end{array}$ & $\begin{array}{l}\text { Daylight } \\
\text { Partial Daylight } \\
\text { Night Good street lighting } \\
\text { Night No street lighting }\end{array}$ \\
\hline $\begin{array}{l}\text { Severity level of the } \\
\text { accident }\end{array}$ & $\begin{array}{l}\text { Property Damage only } \\
\text { Minor } \\
\text { Severe }\end{array}$ \\
\hline $\begin{array}{l}\text { Whether the driver has } \\
\text { consumed alcohol }\end{array}$ & $\begin{array}{l}\text { No } \\
\text { Yes }\end{array}$ \\
\hline Animal crossing & $\begin{array}{ll}\text { 0. } & \text { No } \\
\text { 1. } & \text { Yes } \\
\end{array}$ \\
\hline $\begin{array}{l}\text { Negligence of the driver } \\
\text { during the period of } \\
\text { accident }\end{array}$ & $\begin{array}{ll}0 . & \text { No } \\
\text { 1. } & \text { Yes }\end{array}$ \\
\hline $\begin{array}{l}\text { Driver seems to be } \\
\text { fatigued during the } \\
\text { period of accident }\end{array}$ & $\begin{array}{ll}0 . & \text { No } \\
\text { 1. } & \text { Yes }\end{array}$ \\
\hline $\begin{array}{l}\text { Obstacle was met during } \\
\text { the period of accident }\end{array}$ & $\begin{array}{ll}0 . & \text { No } \\
\text { 1. } & \text { Yes } \\
\end{array}$ \\
\hline $\begin{array}{l}\text { Vehicle fault was } \\
\text { identified during the } \\
\text { period of accident }\end{array}$ & $\begin{array}{ll}0 . & \text { No } \\
\text { 1. } & \text { Yes }\end{array}$ \\
\hline $\begin{array}{l}\text { Toll gate problem was } \\
\text { identified during the } \\
\text { period of accident }\end{array}$ & $\begin{array}{ll}0 . & \text { No } \\
\text { 1. } & \text { Yes }\end{array}$ \\
\hline
\end{tabular}

The study also conducted a live driving experience followed by a photographic survey to identify the structural and environmental characteristics of the Southern Expressway. Further, the study employed the information collected through random interviews with relevant officials including police officers, traffic regulating personnel in order to familiarize with the expressway accidents and to triangulate the results which is a way of assuring the validity of results. Also, Police data and other sources of information have been employed to identify the current situation and trends of accidents in Sri Lanka.

\subsection{Methodology}

The objectives of this study are to find out the severity factors and risk areas of the expressway accidents and finally to develop a policy brief on safety management of expressways in Sri Lanka. In order to achieve above objectives, the study executed both Quantitative and Qualitative techniques.

Quantitative part includes a descriptive statistics section to understand the current situation and the trends in expressway accidents in Sri Lanka. Univariate Analysis was performed to obtain a general understanding of the nature and magnitude of accidents in the Southern Expressway. Under Bivariate analyses, the relationships between the variables were examined by graphical analysis and Pearson Chi-Square contingency table analysis.

Further, the risk areas in the Southern Expressway were mapped to build up a spatial analysis of expressway accidents using "Hotspot Analysis" method. Analysis employed Arc GIS tool, "HOTSPOT ANALYSIS". The tool identifies the significant hot spots and cool spots of accidents. Among 5239 total accident data, 527 observations which included Minor (364) and Severe (163) level accident information, were selected for the analysis.

As the first step, the number of accidents were extracted and tabulated by accident kilometre for both severe and minor level accidents. Then, coordinates of each accident kilometre were generated using "Google Earth Pro" software and included in separate excel sheets. These excel sheets were converted to CSV (commaseparated values) format and inverted to Arc GIS compatible format. After subsequent series of functionalities, the accident-prone locations were obtained for both severe and minor accidents separately. The result represents the hotspots and cool spots of the Southern Expressway accidents by severity level. In order to visualize the results, two digital maps were generated with significant locations.

After identifying the risk areas, the study moves towards finding the reasons for such accidents by accident location. Cross tabulation of reason for the accident and location of the accident by severity level was applied using STATA statistical application. Further, the live recording driving experience followed by a photographic 
survey was conducted to identify the structural and environmental characteristics of the Southern Expressway with special consideration to identified accident prone locations.

In line with the quantitative analysis, qualitative analysis in the latter part of the research will suggest recommendations along with a national policy brief to decrease the number of accidents and severity of accidents in national highways.

\section{Results and Discussion}

\subsection{Preliminary Analysis Results}

According to the accident data of the Southern Expressway collected by the EOMM Division from 2011 to 2018, expressway accidents were categorized into four (04) classes such as Fatal, Grievous, Non-Grievous, and Property Damage. Descriptive Analysis shows that out of the 5239 recorded accidents, around $90 \%$ caused only property damage while having a considerable number of Fatal and Grievous type accidents (Figure 1). In the latter part of the analysis, accidents were analysed based on the severity level. Three (03) severity levels were identified as mentioned in Table 3. Figure 2 shows that the number of accidents reported by each year has been increasing over the years. Compared to the year 2011, number of accidents reported in 2018 had taken a three-digit value. This may be due to either rapid growth of expressway users during the period or changes of accident related factors.

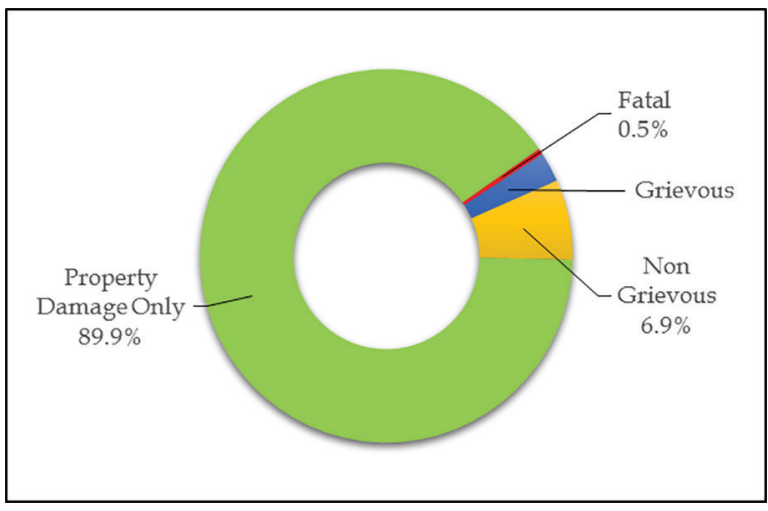

Figure 1 - Types of Accidents

Table 3 - Accidents by Severity Level

\begin{tabular}{|l|c|l|}
\hline \multicolumn{1}{|c|}{ Severity Level } & $\begin{array}{c}\text { No. of } \\
\text { Accidents }\end{array}$ & \multicolumn{1}{c|}{$\%$} \\
\hline Property damage only & 4,712 & 89.94 \\
\hline Minor & 364.00 & 6.95 \\
\hline Severe & 163.00 & 3.11 \\
\hline Total & 5,239 & 100 \\
\hline
\end{tabular}

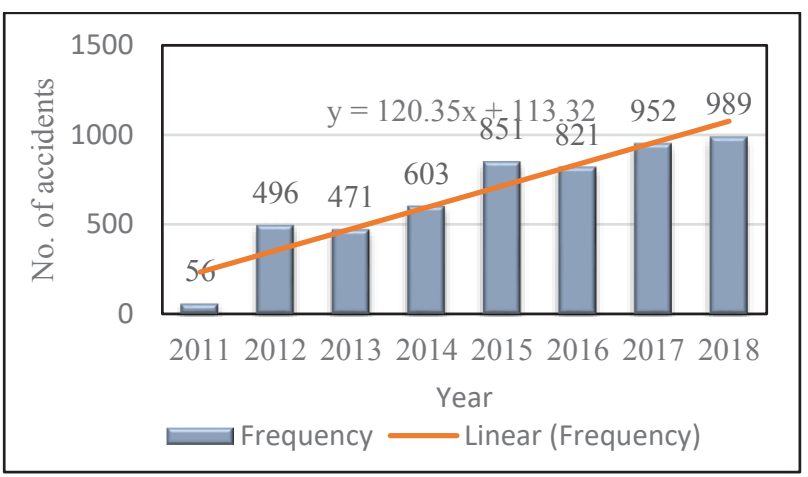

Figure 2 - Trends of Accidents by Year (20112018)

EMMO Division data includes the information on nearest reason for the accident occurred in expressway. According to the EMMO Division information, there was considerable amount of reasons for the accidents and summarized reasons are as included in Figure 3.

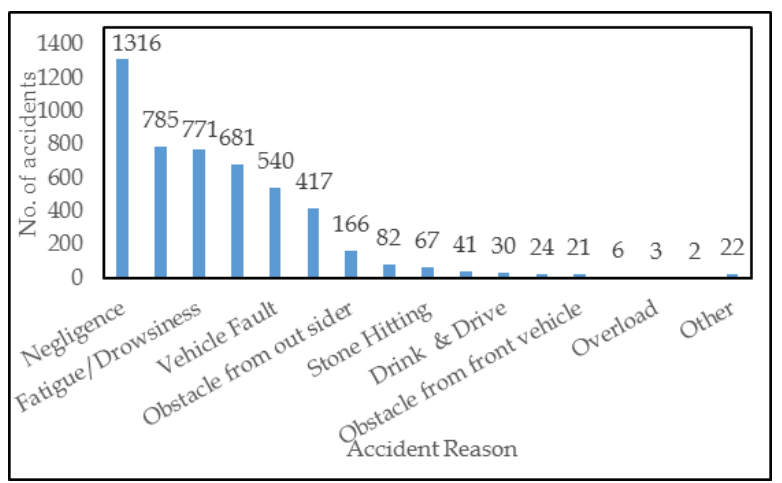

Figure 3 - Accident Reasons in Southern Expressway

The above figure further illustrates reasons for the expressway accidents using a hierarchical order. According to the line graphs, top six (06) reasons were Negligence, Animal Crossing, Fatigue/Drowsiness, weather, Vehicle Fault and Overtake. Results did not have any significant deviation compared to the previous studies. Even though the Overtake had been separated as sixth $\left(6^{\text {th }}\right)$ highest reason, this could be considered into the highest reason, Negligence. Further, the interesting finding of the accident reasons was Animal Crossing. This finding verifies the opinion among general public that animal crossing is a major problem in the Southern expressway. Further, analysis on types of animals which crossed the Southern Expressway and caused accidents identified that birds and dogs are the most influencers (Table 4). 
Table 4 - Types of Animals Crossing Southern Expressway

\begin{tabular}{|l|c|c|}
\hline $\begin{array}{c}\text { Animal } \\
\text { Type }\end{array}$ & No. of Accidents & $\mathbf{\%}$ \\
\hline Bird & 210 & 30.26 \\
\hline Dog & 311 & 44.81 \\
\hline Monkey & 38 & 5.48 \\
\hline Pig & 90 & 12.97 \\
\hline Other & 45 & 6.48 \\
\hline Total & 694 & \\
\hline
\end{tabular}

According to the Haddon [2] and other studies, reasons for the accidents can be placed into three (03) major categories as Human Factors, Vehicles \& Equipment Factors and Environmental Factors. Above mentioned reasons of accidents were compressed under three major categories and their contribution by severity levels are represented in Figure 4. According to the figure, highest contribution factor for any severity level was human related factors. This result agreed with the previous studies. However, the contribution of human factors was relatively higher in minor and severe accidents compared to property damage only accidents.

Table 5 shows that null hypothesis of Chi-Square Test of Independence was rejected as the $p$-value was less than the significance level $(a=0.05)$. Hence, the test statistics concluded that there was a significant association between severity levels and accident factors.

$\mathbf{H}_{0}$ : There is no association between variables

$\mathbf{H}_{1}$ : There is an association between variables

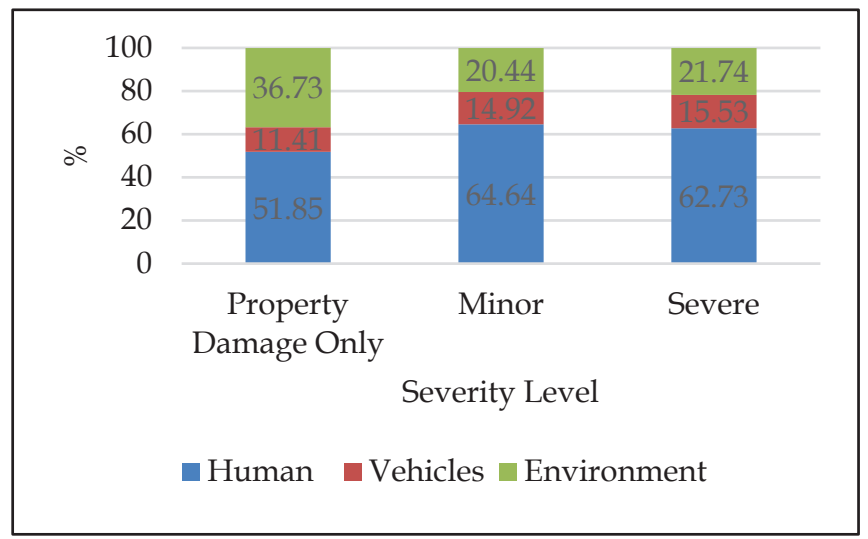

Figure 4 - Contribution of Major Factors by Severity Level
Table 5 - Cross Tabulation of Severity and Accident Factors

\begin{tabular}{|c|c|c|c|c|}
\hline \multirow{2}{*}{$\begin{array}{c}\text { Severity } \\
\text { Level }\end{array}$} & \multicolumn{4}{|c|}{ Accident Factors } \\
\cline { 2 - 5 } & Human & Vehicle & Environment & Total \\
\hline $\begin{array}{c}\text { Property } \\
\text { Damage } \\
\text { Only }\end{array}$ & $\begin{array}{c}2308 \\
(51.85 \%)\end{array}$ & $\begin{array}{c}508 \\
(11.41 \%)\end{array}$ & $1635(36.73 \%)$ & 4451 \\
\hline Minor & $\begin{array}{c}234 \\
(64.64 \%)\end{array}$ & $\begin{array}{c}54 \\
(14.92 \%)\end{array}$ & $74(20.44 \%)$ & 362 \\
\hline Severe & $\begin{array}{c}101 \\
(62.73 \%)\end{array}$ & $\begin{array}{c}25 \\
(15.53 \%)\end{array}$ & $35(21.74 \%)$ & 161 \\
\hline Total & $\begin{array}{c}2643 \\
(53.14 \%)\end{array}$ & $\begin{array}{c}587 \\
(11.8 \%)\end{array}$ & $174435.06 \%)$ & 4974 \\
\hline \multicolumn{5}{|c|}{ Pearson chi2(4)=52.39Pr $=0.000$} \\
\hline
\end{tabular}

Further, the association between severity and selected individual factors were analysed using Chi-Square Test of Independence and the summary of the results is as follows (Table 6).

Table 6 - Summary Statistics of chi- Square Test of Selected Accident Factors vs Severity Type

\begin{tabular}{|l|c|c|c|c|}
\hline \multicolumn{1}{|c|}{ Variable } & DF & $\begin{array}{c}\text { Pearson } \\
\text { chi2 }\end{array}$ & $\begin{array}{c}\text { P } \\
\text { value }\end{array}$ & Significance \\
\hline $\begin{array}{l}\text { Accident } \\
\text { Informed Time } \\
\text { and Severity }\end{array}$ & 4 & 14.43 & 0.006 & Significant \\
\hline $\begin{array}{l}\text { Accident } \\
\text { Direction and } \\
\text { Severity }\end{array}$ & 4 & 1.15 & 0.886 & $\begin{array}{c}\text { Not } \\
\text { Significant }\end{array}$ \\
\hline $\begin{array}{l}\text { Road Condition } \\
\text { and Severity }\end{array}$ & 2 & 15.25 & 0.000 & Significant \\
\hline $\begin{array}{l}\text { Weather } \\
\text { Condition and } \\
\text { Severity }\end{array}$ & 4 & 16.64 & 0.002 & Significant \\
\hline $\begin{array}{l}\text { Light Condition } \\
\text { and Severity }\end{array}$ & 6 & 8.09 & 0.231 & $\begin{array}{c}\text { Not } \\
\text { Significant }\end{array}$ \\
\hline $\begin{array}{l}\text { Alcohol and } \\
\text { Severity }\end{array}$ & 2 & 9.62 & 0.008 & Significant \\
\hline $\begin{array}{l}\text { Animal Crossing } \\
\text { and Severity }\end{array}$ & 2 & 63.8 & 0.000 & Significant \\
\hline $\begin{array}{l}\text { Negligence and } \\
\text { Severity }\end{array}$ & 2 & 13.38 & 0.001 & Significant \\
\hline $\begin{array}{l}\text { Fatigue and } \\
\text { Severity }\end{array}$ & 2 & 14.14 & 0.001 & Significant \\
\hline $\begin{array}{l}\text { Obstacle and } \\
\text { Severity }\end{array}$ & 2 & 17.87 & 0.000 & Significant \\
\hline $\begin{array}{l}\text { Vehicle fault and } \\
\text { Severity }\end{array}$ & 2 & 12.87 & 0.002 & Significant \\
\hline $\begin{array}{l}\text { Toll Gate } \\
\text { problem and } \\
\text { Severity }\end{array}$ & 2 & 4.62 & 0.099 & $\begin{array}{c}\text { Not } \\
\text { Week or } \\
\text { weekend and } \\
\text { Severity }\end{array}$ \\
\hline $\begin{array}{l}\text { Overtake and } \\
\text { Severity }\end{array}$ & 2 & 4.452 & 0.108 & $\begin{array}{c}\text { Not } \\
\text { Significant }\end{array}$ \\
\hline $\begin{array}{l}\text { Sudden break } \\
\text { and Severity }\end{array}$ & 2 & 18.42 & 0.000 & Significant \\
\hline
\end{tabular}


The above table illustrates that Accident Direction, Light Condition and Toll Gate Problem did not indicate any significant relationship with severity levels.

\subsection{Risk Area Analysis (Accident-Prone Locations) Results}

Arc GIS based hotspot analysis results identified accident prone locations with respect to minor and severe level accidents. Risk areas with 99\% and $95 \%$ confidence level are summarized in Table 7.

Table 7 - Accident Prone Locations-Southern Expressway by Severity Level

\begin{tabular}{|c|c|c|}
\hline $\begin{array}{c}\text { Severity } \\
\text { Level }\end{array}$ & $\begin{array}{c}\text { Accident Prone } \\
\text { Locations (99\% c.l) }\end{array}$ & $\begin{array}{c}\text { Accident Prone } \\
\text { Locations (95\% c.l) }\end{array}$ \\
\hline Severe & $23,42,43,55,94$ & $21,22,56$ \\
\hline Minor & $21,22,55,56$ & $1,11,23,65,66$ \\
\hline
\end{tabular}

With respect to severity level, there is a high probability for occurrence of a severe level accident within the radius of 23, 42, 43, 55 and $94 \mathrm{~km}$ milestones. Further, the 23, 22 and $56 \mathrm{~km}$ milestones are also critical with $95 \%$ confidence. With regard to the Minor category accidents within the radius of $21,22,55,55 \mathrm{~km}$ milestones show a statistically significant $(99 \%$ confidence level) probability for occurrence of an accident. Moreover, 1, 11, 23, 65, $66 \mathrm{~km}$ milestones also can be identified as a risk area.

Figure 5 and Figure 6 respectively show the identified Accident-Prone Locations in the Southern Highway for Severe and Minor level accidents with confidence levels. With regard to severe accidents, majority of the accident-prone locations were identified in the first half of the expressway from Kottawa interchange. Also, it was noticed that identified accident prone locations for severe accidents illustrate three major clusters. When we consider the accidentprone locations for minor level accidents, possibility of occurring an accident was identified totally between $0-66 \mathrm{~km}$ milestones. Most interesting part was that $0 \mathrm{~km}$ milestone also showed a possibility for occurrence of minor level accident. Excluding 0 and $11 \mathrm{~km}$ mile stones, other accident-prone locations showed the same clustering pattern as identified for severe level accidents. However, those two $\mathrm{km}$ milestones were identified with 95\% confidence level while other locations indicate 99\% confidence level.

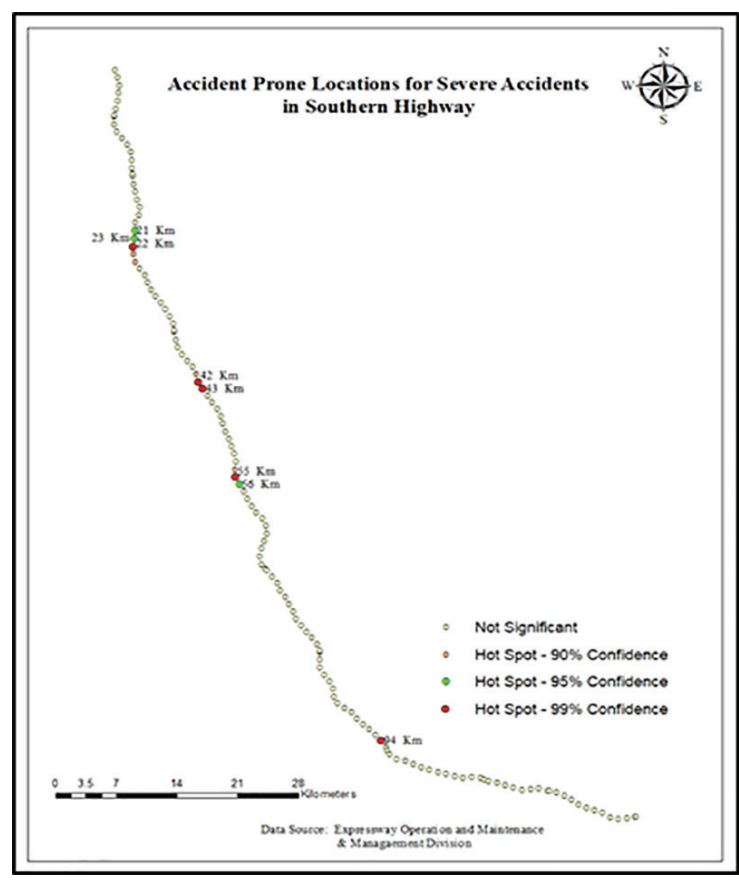

Figure 5 - Accident Prone Locations for Severe Accidents in Southern Expressway

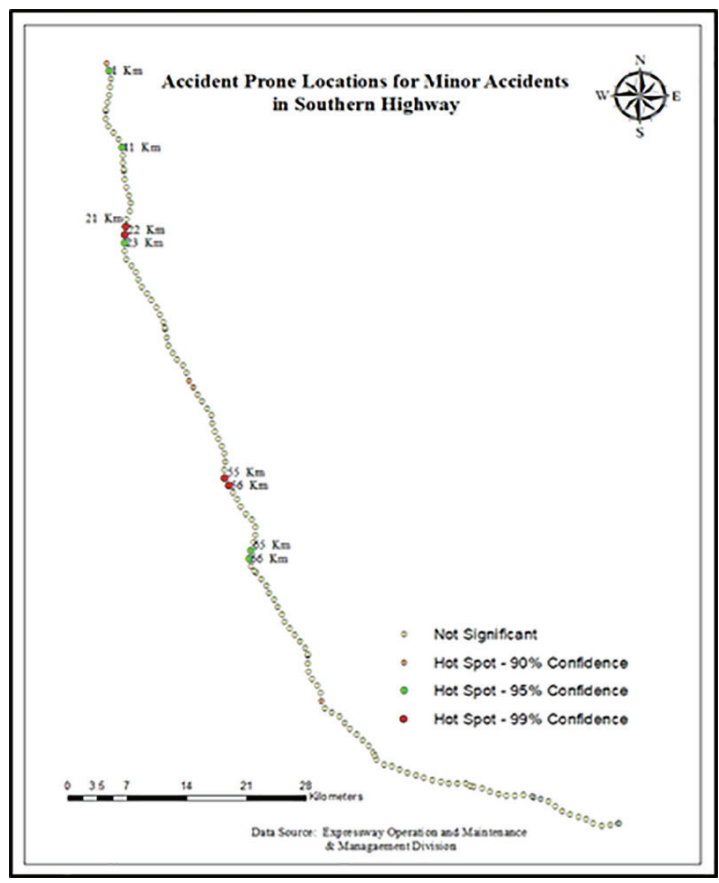

Figure 6 - Accident Prone Locations for Minor Accidents in Southern Expressway

Based on the accident-prone locations with 99\% and $95 \%$ confidence, accident reasons and their frequencies were tabulated for each prone location $(\mathrm{km})$. According to Table 8 and Table 9, majority of the severe category accidents occurred due to driver related factors such as drink \& drive, negligence, fatigue and overtake. Bad weather condition is also a considerable factor. 
Table 8 - Accident Prone Locations and Accident Reasons for Severe Accidents in Southern Expressway (C.L = 99\%)

\begin{tabular}{|c|c|l|}
\hline $\begin{array}{c}\text { Accident } \\
\mathbf{~ k m}\end{array}$ & $\begin{array}{c}\text { No of } \\
\text { accidents }\end{array}$ & Accident Reasons (\%) \\
\hline 23 & 3 & $\begin{array}{l}\text { Negligence (66.67) } \\
\text { Vehicle Fault (33.33) }\end{array}$ \\
\hline 42 & 4 & $\begin{array}{l}\text { Negligence (25) } \\
\text { Sudden Brake (25) } \\
\text { Weather (50) }\end{array}$ \\
\hline 43 & 5 & $\begin{array}{l}\text { Negligence (40) } \\
\text { Fatigue/Drowsiness (20) } \\
\text { Vehicle Fault (20) } \\
\text { Weather (20) }\end{array}$ \\
\hline 55 & 6 & $\begin{array}{l}\text { Negligence (50) } \\
\text { Vehicle Fault (16.67) } \\
\text { Weather (33.33) }\end{array}$ \\
\hline 94 & 2 & $\begin{array}{l}\text { Obstacle (50) } \\
\text { Overtake (50) }\end{array}$ \\
\hline
\end{tabular}

Table 9 - Accident Prone Locations and Accident Reasons for Severe Accidents in Southern Expressway (C.L = 95\%)

\begin{tabular}{|c|c|l|}
\hline $\begin{array}{c}\text { Accident } \\
\mathbf{~ k m}\end{array}$ & $\begin{array}{c}\text { No of } \\
\text { accidents }\end{array}$ & Accident Reasons (\%) \\
\hline 23 & 6 & $\begin{array}{l}\text { Drink \& Drive (16.67) } \\
\text { Negligence (33.33) } \\
\text { Fatigue/Drowsiness (50) }\end{array}$ \\
\hline 56 & 3 & $\begin{array}{l}\text { Negligence (66.67) } \\
\text { Weather (33.33) }\end{array}$ \\
\hline
\end{tabular}

With regard to minor accidents, cross tabulation shows the same findings (Table 10 and Table 11). However, within the radius of $22 \mathrm{~km}$ and 55 $\mathrm{km}$ milestones, animal crossing was identified as one of the factors for minor accidents.

Table 10 - Accident Prone Locations and Accident Reasons for Minor Accidents in Southern Expressway (C.L = 99\%)

\begin{tabular}{|c|c|l|}
\hline $\begin{array}{c}\text { Accident } \\
\mathbf{k m}\end{array}$ & $\begin{array}{c}\text { No of } \\
\text { accidents }\end{array}$ & Accident Reasons (\%) \\
\hline 21 & 5 & $\begin{array}{l}\text { Negligence (20) } \\
\text { Overtake (40) } \\
\text { Vehicle Fault (20) } \\
\text { Weather (20) }\end{array}$ \\
\hline 22 & 8 & $\begin{array}{l}\text { Animal Crossing (12.5) } \\
\text { Negligence (37.5) } \\
\text { Fatigue/Drowsiness (12.5) } \\
\text { Overtake (25) } \\
\text { Vehicle Fault (12.5) }\end{array}$ \\
\hline 55 & 12 & $\begin{array}{l}\text { Animal Crossing (16.67) } \\
\text { Negligence (16.67) } \\
\text { Fatigue/Drowsiness (33.33) } \\
\text { Weather (33.33) }\end{array}$ \\
\hline 56 & 8 & $\begin{array}{l}\text { Negligence (12.50) } \\
\text { Fatigue/Drowsiness (50) } \\
\text { Vehicle Fault (12.50) } \\
\text { Weather (25) }\end{array}$ \\
\hline
\end{tabular}

Table 11 - Accident Prone Locations and Accident Reasons for Minor Accidents in Southern Expressway (C.L = 95\%)

\begin{tabular}{|c|c|l|}
\hline $\begin{array}{c}\text { Accident } \\
\mathbf{k m}\end{array}$ & $\begin{array}{c}\text { No of } \\
\text { accidents }\end{array}$ & Accident Reasons (\%) \\
\hline 1 & 3 & $\begin{array}{l}\text { Drink \& Drive (33.33) } \\
\text { Overtake (33.33) } \\
\text { Weather (33.33) }\end{array}$ \\
\hline 11 & 1 & Negligence (100) \\
\hline 23 & 8 & $\begin{array}{l}\text { Negligence (25) } \\
\text { Fatigue/Drowsiness (12.50) } \\
\text { Obstacle (12.50) } \\
\text { Overtake (25) } \\
\text { Vehicle Fault (12.50) } \\
\text { Weather (12.50) }\end{array}$ \\
\hline 65 & 2 & $\begin{array}{l}\text { Fatigue/Drowsiness (50) } \\
\text { Obstacle from outside (50) }\end{array}$ \\
\hline 66 & 3 & $\begin{array}{l}\text { Fatigue/Drowsiness (66.67) } \\
\text { Vehicle Fault (33.33) }\end{array}$ \\
\hline
\end{tabular}

\subsection{Live Recording Driving Experience and Photographic Survey Results}

Supporting the tabulated reasons for the severity of accidents in the accident-prone locations, live recording and photographic survey analysis made significant observations and findings.

Structural characteristics of the road and spatial characteristics of the roadside landscape for identified key locations in the Southern Expressway is summarized in Table 12.

According to the live recording driving experience followed by a photographic survey of identified key locations imply that there is lack of variations of forms and scenery due to green surrounding along the expressway. This might lead to monotones and fatigue driving experiences.

Table 12 - Structural and Spatial Characteristics in Identified Locations of Southern Expressway Landscape

\begin{tabular}{|c|l|}
\hline $\begin{array}{c}\text { Location } \\
(\mathbf{k m})\end{array}$ & $\begin{array}{l}\text { Structural and Spatial Characteristics } \\
\text { in Identified Locations of Southern } \\
\text { Expressway Landscape }\end{array}$ \\
\hline \multirow{1}{*}{11} & $\begin{array}{l}\text { road sections with bends, Green } \\
\text { surroundings with open space, low } \\
\text { variation of solid- voids, lack of } \\
\text { variations of forms, significant } \\
\text { elevation more than the observer. }\end{array}$ \\
\hline & $\begin{array}{l}\text { road sections with bends, Green } \\
\text { surroundings with random open } \\
\text { lands, low variation of solid- voids, } \\
\text { lack of variations of forms, includes } \\
\text { narrow road sections, mixed with } \\
\text { enclosed and open spaces. }\end{array}$ \\
\hline
\end{tabular}




\begin{tabular}{|c|c|}
\hline $21,22,23$ & $\begin{array}{l}\text { road sections with bends, Green } \\
\text { surroundings mixed with solid rock } \\
\text { surfaces, lack of variations of forms, } \\
\text { includes narrow road sections, mostly } \\
\text { includes lower proportion sections } \\
\text { with open spaces. }\end{array}$ \\
\hline 42,43 & $\begin{array}{l}\text { road sections with bends, Green } \\
\text { surroundings with mixed rock } \\
\text { surfaces, lack of variations of forms, } \\
\text { includes narrow road sections, } \\
\text { composition of enclosed and open } \\
\text { areas, proportion is slightly larger } \\
\text { than the observer. }\end{array}$ \\
\hline 55,56 & $\begin{array}{l}\text { road sections with more bends, Green } \\
\text { surroundings, lack of variations of } \\
\text { forms, includes narrow road sections, } \\
\text { lower proportion and no variation of } \\
\text { solid- voids towards the Matara lane. } \\
\text { Enclosed spaces towards to Kottawa } \\
\text { lane. }\end{array}$ \\
\hline 65,66 & $\begin{array}{l}\text { road sections with bends, Green } \\
\text { surroundings, includes narrow road } \\
\text { sections, Hard solid rock surfaces } \\
\text { towards Kottawa lane, composition of } \\
\text { enclosed and open spaces. }\end{array}$ \\
\hline 94 & $\begin{array}{l}\text { road sections with bends, includes } \\
\text { narrow road sections, Green } \\
\text { surroundings, lack of variations of } \\
\text { forms, mostly includes lower } \\
\text { proportion sections, More Open } \\
\text { spaces towards the Matara lane, Hard } \\
\text { solid rock surfaces towards Kottawa } \\
\text { lane, Random void spaces towards the } \\
\text { Matara lane. }\end{array}$ \\
\hline
\end{tabular}

Note: Structural and Spatial characteristics of the locations were taken within the area of $1 \mathrm{~km}$ radius of each identified location.

It is notable that most of the identified accident locations consist of road sections with bends and narrow road sections (Figure 7). Between 54 and $55 \mathrm{~km}$ stretch recorded a higher number of bends and narrow road sections. Between narrow shoulders and bends, there is a possibility of having a road crash. This is because divers cannot control or stop the vehicle at such sudden narrow spaces with the speed they drove through the expressway.

It was also found that expressway management unit had already identified certain locations (between 21-22 and 55-56 km sections) which were recognized in this research also as critical areas and fixed hazard signs (Figure 8). Impact of bend and narrow road sections become worst in the night driving and drive through rainy days.

Live recording also found and the expressway officials also confirmed that anti-reflective boards in the centre median exist only between 24 and $26 \mathrm{~km}$ stretches. This can be identified as a significant drawback and a root cause for higher number of accidents in the Southern Expressway, especially with respect to night driving against traffic. The effect would be more in rainy days.

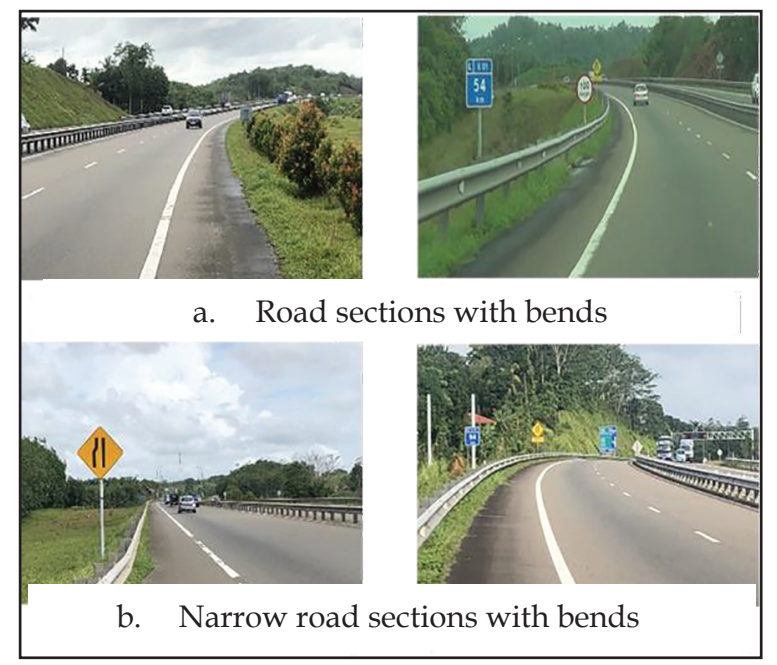

Figure 7 - Road Characteristics of Southern Expressway

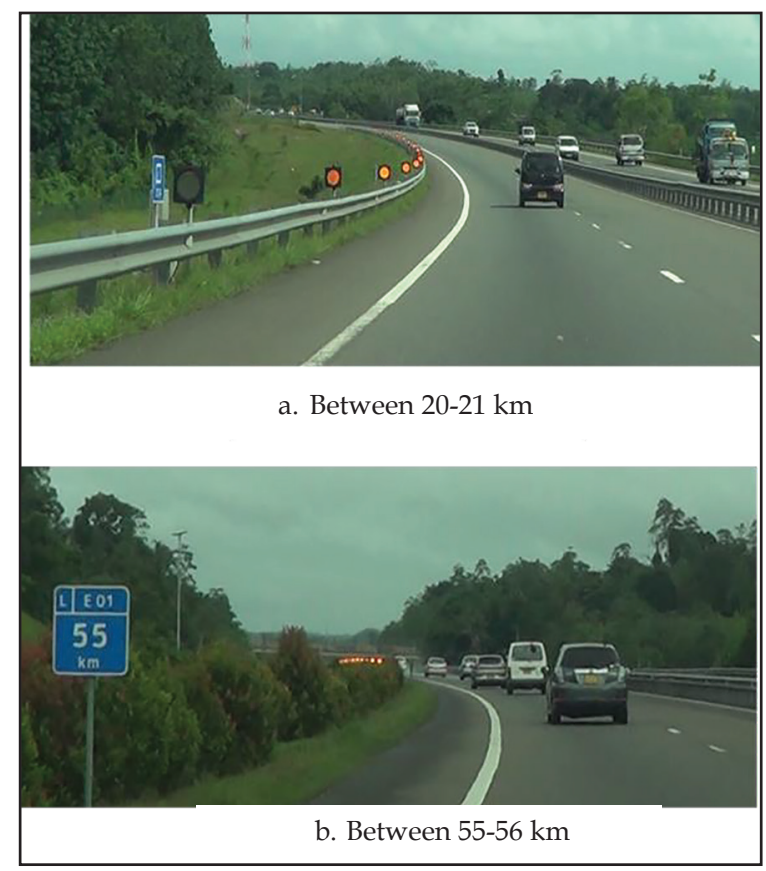

Figure 8 - Critical Areas with Hazard Signs

Figure 9 and Figure 10 illustrate the night driving risk without anti-reflective boards. 


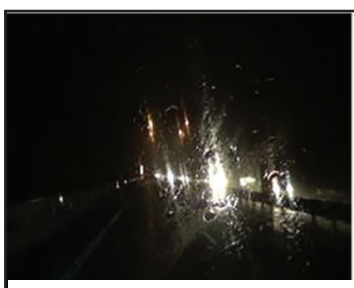

a. Driving without antireflectors (No rain)

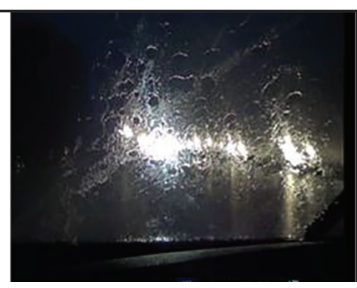

b. Driving without antireflectors on rainy days
Figure 9 - Night Driving Risk without AntiReflective Boards

It was observed that driving without antireflective boards in the night creates a disturbing driving experience. Also, the nonexistence of anti-reflective boards will intensify the impact against light. Further, live driving experience concludes that driving in the night with rainy conditions worsen the impact.

Figure 10-b shows the lessening of impact against light between 24 and $26 \mathrm{~km}$ stretch which has already installed anti-reflective boards.

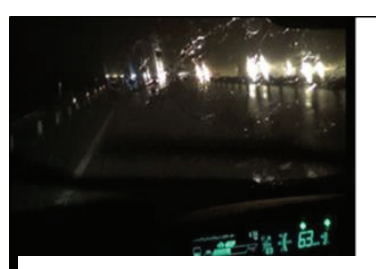

a. Against light without anti-reflective boards

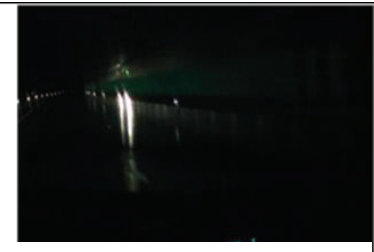

b. Against light with anti-reflective boards
Figure 10 - Impact of against Light with and without Anti-Reflective Boards

Among general observations, it was found that the Southern Expressway does not possess a continuously stationed street light system. Street lights are fixed at specified locations such as interchanges and narrow road stretches across bridges only. This will contribute significantly for night time accidents and their severity.

As shown in Figure 11, road clearness is less in the night with no streetlight system in the southern expressway. Also, it was observed that the impact of non-existence of continuous street light systems becomes worse while driving in the night with rainy condition. According to Figure 11-b, drivers face greater difficulties while driving in the night with rainy situation. Impact against lights of vehicles due to nonexistence of anti-reflexive boards would worsen the situation.
However, it was noted that the Expressway Management Unit had been taking every possible effort to minimize accidents and their severity. Live recording identified that sign boards and hazard signs have been establish where applicable.

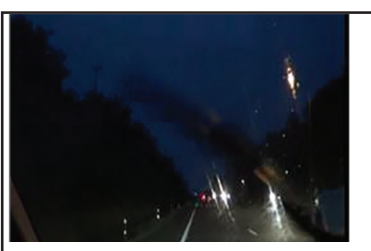

a. Road clearness with no street light in the night

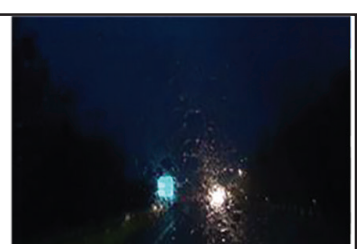

b. Road clearness with no street light with rainy condition in the night
Figure 11 - Impact of Driving without Street Lights

During the live recording, some additional notable facts were identified. With regard to the road surface, buffer line is not wide enough to stop a vehicle in an emergency or break down. When enquired, expressway officials also acknowledged that several accidents happened while vehicles stop by road side due to breakdowns. It was also noted that some expressway users had parked their vehicles and rest in certain stretches which were reserved for expressway unit vehicles and police vehicles. Further, the expressway management highlighted that this is much higher during night time.

Discussions had with the expressway officials revealed the following facts. They have observed that the expressway users who have taken their driving licenses recently (with less experience after obtaining the driving license) are more likely to meet with an accident. Driving behaviour of the lady drivers, especially with regard to signalling, turning and sudden stopping are some of the major risk factors. It was also revealed that drunk drivers are the other significant factor. Further, they explained that some of the expressway users consume liquor while being on the highway.

The stop/park on the expressway was identified as their key concerns on accidents (Figure 12). Especially in the night time, it was said that this is a more common situation. This was also confirmed during the live recording and photographic survey conducted within this study.

During the live recording, it was observed that vehicle related factors exist in the vehicles 
running in the highway. As depicted in Figure 13, signal lights, rear fog lamps and parking lights of such vehicles were not working properly, and this may cause accidents in the night time.

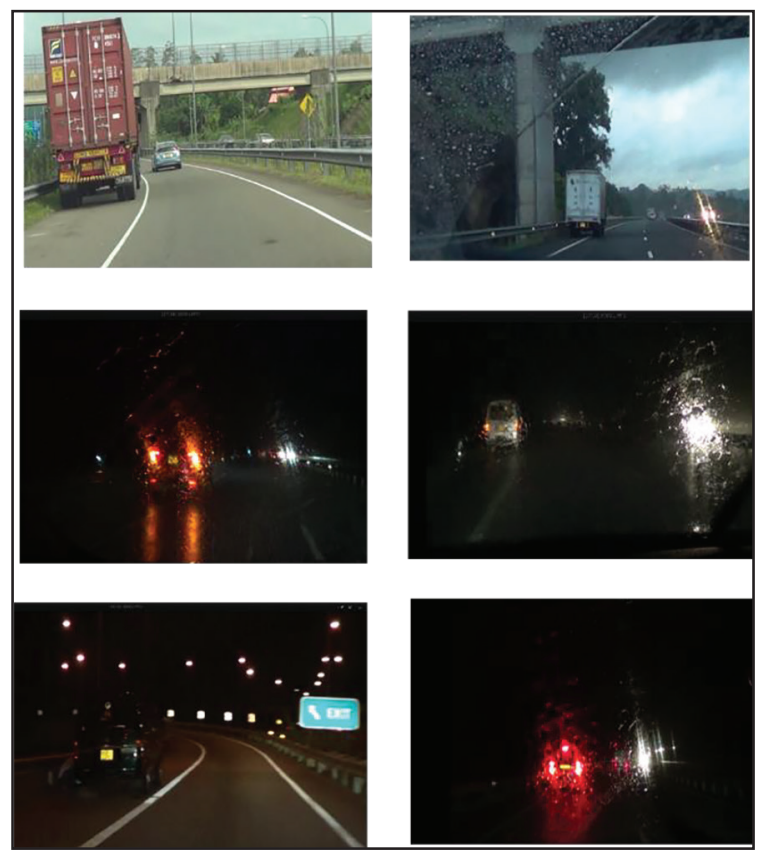

Figure 12 - Parked/ Stopped Vehicles at the Side of the Expressway

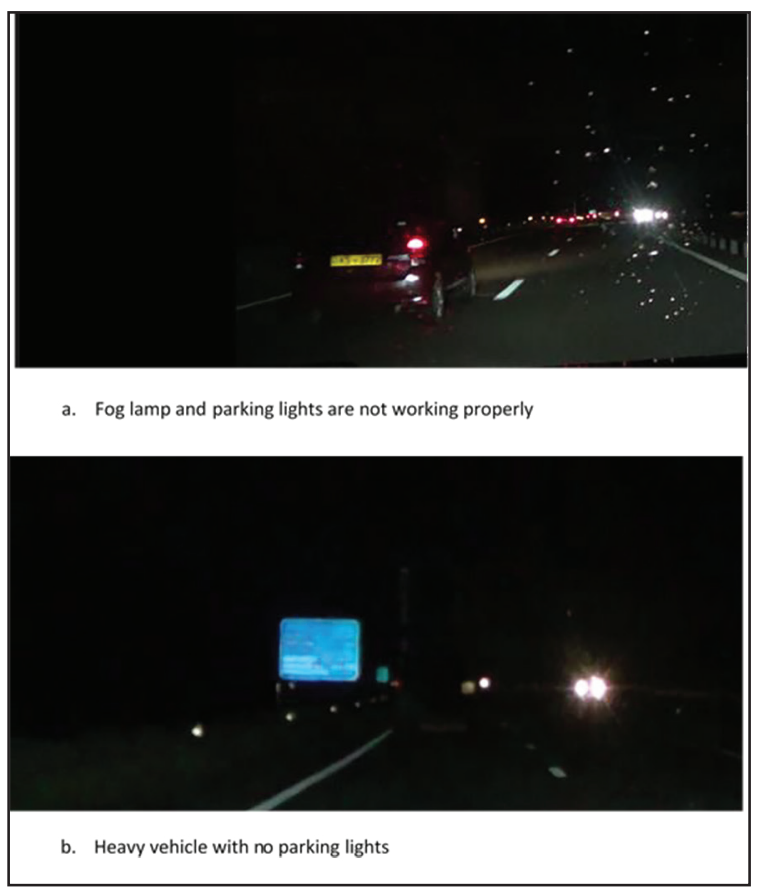

Figure 13 -Technical Faults of the Vehicles

On the other hand, the officials have noticed that overloading also contributes towards expressway crashes. It was notable that most of the highway users have limited knowledge about the exits and entrances. The expressway team pointed out that most of the users try to finish their destination without considering their fatigue and getting some rest by exiting from an interchange halfway their journey, take some rest and continue the journey by entering the highway thereafter. They believe that highway users are in a mind-set that they can't take early exists (prior to their designated exit), rest for some time and re - enter the expressway. Some are also of the opinion that they are required to pay more tolls if they take an exit before the destination. However, the officers noted that the difference of payment is merely about Rs. 50/- for such activity. This is an important point that people should be made aware of the option to exit and rest when tired and re-enter and continue the journey.

\section{Conclusion and Recommendations}

\subsection{Conclusion}

This study has specifically considered the trends, severity factors and accident-prone locations of the expressway in order to identify policy implications and practical solutions to control expressway accidents and mitigate their severity levels. According to the information, an upward trend was noted in the Southern Expressway accidents. Among the 5239 of recorded accidents, property damage accidents counted for $90 \%$ and minor and severe accidents accounted for $7 \%$ and $3 \%$, respectively.

Top six (06) reasons for accident were Negligence, Animal Crossing, Fatigue/Drowsiness, Weather Condition, Vehicle Fault and Overtake. Accordingly, it was found that human factors have contributed more towards reasons for accidents in the Southern Expressway. In agreement with the previous studies, this analysis also reflected that the highest contribution factor for any severity level was human related factors.

Accident prone location analysis identified specific locations which are high probability areas for severe and minor level accidents. Majority of the severe category accidents were due to driver related factors and bad weather condition is a considerable factor on minor accidents. However, in 22 and $55 \mathrm{~km}$ milestones, animal crossing was identified as one of the key factors for minor accidents.

Live recording of a driving experience followed by photographic survey of identified key locations reflect that Structural and Spatial characteristics of the roadside landscape as significant factors for the severity level of the expressway accidents. Impact of above 
characteristics become worse during night time driving and when driving on rainy days.

Expressway management officials highlighted that parking of vehicles and resting in certain stretches by expressway users, especially during night time, drunk driving and consumption of liquor within the highway by the expressway users, drivers with recent driving licences, driving behaviour of the lady drivers, and overloading of vehicles are major risk factors connected with the accidents in the Southern Expressway.

\subsection{Recommendations and Policy Implication on Safety Management of Expressways}

Expressway accidents cause deaths and property damages all over the world. Sri Lanka is also now facing these challenges after introducing the expressways into the Country's transport system. On the other hand, the expressway system mostly contributes to the economic development of the country as a driving factor. Therefore, country needs policies to control or reduce expressway accidents and their severity in order to get the maximum benefits of expressway system.

When considering the accident trends, it was clear that there had been an increasing trend of accidents in the Southern Expressway during the last eight (08) years. Therefore, there is an immediate requirement to implement policies in order to reduce the numbers of accidents via identifying the factors contributing for such accidents and take precautionary measures accordingly.

Following results of other studies on the accidents in the Southern Expressway, the current study also identified that majority of the reasons among expressway accidents were due to human related factors such as negligence, fatigue/ drowsiness, drunk driving and overtake. With respect to drunk driving, there should be strict policies and random checking, especially to ensure that there will be no consumption of alcohol when driving on the expressway.

Animal Crossing is also still shown to be a considerable factor for property damage accidents in the Southern Expressway. Therefore, the Express Management Unit needs to re-assess this issue and take immediate actions in order to reduce the number of accidents causing only property damage.
In agreement with the other studies, the current study also confirmed that driving speed involved with the accidents has a significant chance of having minor and severe level accidents. It is recommended to install speed tracking systems in the expressway while establishing mobile units by the police to monitor speed limits on a regular basis.

Road characteristics, such as road section with bends and narrow road sections, non-existence of anti-reflective boards in the centre median; and not having a continuously stationed streetlight system, contribute significantly for accidents and their severity. As the Southern Expressway does not process a continuously running street lighting system, driving in the night with no streetlights and/or anti-reflective boards showed a greater possibility of having severe accidents. Therefore, it is recommended to install continuously stationed streetlight systems and anti-reflective boards in the Southern Expressway. It is also recommended to install hazard warning signs for accident prone locations identified in the study.

Studies including the current study have found that when constructing expressways, landscape and structural characteristics also should be considered to ensure minimum disruption for highway users. Therefore, it is recommended to prepare a national guideline or a Highway Code which considers all possible factors to create minimum disruption in terms of environment as well as expressway accidents in the future.

\section{References}

1. World Health Organization., Global status report on road safety 2018, Switzerland, 2018.

2. Haddon, W., "A Logical Framework for Categorizing Highway Safety Phenomena and Activity",J. Trauma, Vol. 12 , No. 03, 1972, pp. 193-207.

3. Petridou, E., \& Moustaki, M., "Human Factors in the Causation of Road Traffic Crashes", Eur. J Epidemiol., Vo.16, No. 09, 2000, pp. 819-826.

4. Suriyawongpaisal, P., \& Kanchanasut, S., "Road Traffic Injuries in Thailand: Trends, Selected Underlying Determinants and Status of Intervention", Inj. Control Saf. Promot., Vol.10, No. 02, 2010, pp. 95-104.

5. Hijar, M., Carrillo, C., Flores, M., Anaya, R., \& Lopez, V., "Risk Factors in Highway Traffic Accidents: A Case Control Study", Accid. Anal. Prev., Vol. 32, No. 05, 2000, pp. 703-709. 
6. Åkerstedt, T., Kecklund, G., \& Hörte, G., “Night Driving, Season, and the Risk of Highway Accidents", Sleep., Vol. 24, No. 4, 2001, pp. 101406.

7. Åkerstedt, T., \& Kecklund, G., “Age, Gender and Early Morning Highway Accidents", J. Sleep Res., Vol.10, No. 02, 2001.

8. Boni, J. A., Chowdhury, T. R., \& Das, S. S., "A Study on Causes of Road Accidents at Dhaka to Comilla Highway", Int. j. innov. res. sci. eng. technol.,Vol. 1, No.09, 2016.

9. Peter,T.S., Fred, L. M., Dominique, L.,\& Mohammed, A. Q., "The Statistical Analysis of Highway Crash-Injury Severities: A Review and Assessment of Methodological Alternatives"., Accid. Anal. Prev., Vol. 43, 2011, pp.1666-1676.

10. DeOña, J., Mujalli, R. O., \& Calvo, F. J., "Analysis of Traffic Accident Injury Severity on Spanish Rural Highways using Bayesian Networks", Accid. Anal. Prev., Vol. 43, No.01, 2011, pp. 402-411.

11. Osoro, E., Ng' Z., Oundo, J., Omolo, J., "Factors Associated with Severity of Road Traffic Injuries in Thika, Kenya", Pan. Afr. Med. J., Vol. 8, No. 01, 2011, pp. 121-129.

12. Liyanage,L., "Using Logistic Regression to Estimate the Influence of Environmental Factors on Motor Cycle Road Crash Severity", Proc.,International Postgraduate Research Conference, 2019.

13. Jayaratne, P., \& Kumarage, A., "Analysis of Trends in Fatal Accidents of Vulnerable Road Users In Sri Lanka",2006.

14. Dhananjaya, S. A. T., \& Alibuhtto, M. C., "Factors Influencing Road Accidents in Sri Lanka: A Logistic Regression Approach", Proc.,55 Annual Science Research Sessions, 2016.

15. Renuraj, S., Varathan, N., \& Satkunananthan, N., "Factors Influencing Traffic Accidents in Jaffna", SriSri Lankan J. Appl. Stat., Vol.16, No. 02, 2015.

16. Senanayake,I., Tdc, P., Uga, P., \& Maduranga, M., "Impact of Rain on Road Accidents in Sri Lanka", Global J. of Eng.Appl. Sci., Vol. 04, 2012, pp. $297-300$

17. Lakshmi, S., Srikanth, I., \& Arockiasamy, M. "Identification of Traffic Accident Hotspots using Geographical Information System(GIS)", Int. J. Eng. Adv. Technol., Vol. 09, No. 02, 2019, pp. 4429-4438.

18. Truong, L. T., \& Somenahalli, S. V. C. , "Using GIS to Identify Pedestrian-Vehicle Crash Hot
Spots and Unsafe Bus Stops", J. Public Trans., Vol.14, No.01, 2011, pp. 99-114.

19. Shariff, S. S. R., Maad, H. A., Halim, N. N. A., \& Derasit, Z., "Determining Hotspots of Road Accidents using Spatial Analysis", Indonesian J. Electr. Eng. Comput. Sci., Vol.9, No.01, 2018, pp. 146-151.

20. Le, K. G., Liu, P., \& Lin, L.T.,"Determining the Road Traffic Accident Hotspots using GISBased Temporal-Spatial Statistical Analytic Techniques in Hanoi, Vietnam", Geo. Spat. Inf. Sci., Vol. 23, No. 02, 2020, pp. 153-164.

21. Chinthanie, R. P. D. , Accident Analysis of Southern Expressway, University of Moratuwa, 2015.

22. Dharmasena, S., \& Edirisooriya, S. (2018). "Impact of Roadside Landscape to Driving Behaviour; Lessons from Southern Highway, Sri Lanka", Int. J. UrbanEnviron., Vol. 3, No. 01, 2018, pp. 66-86.

23. Getis, A., \& Ord, J. K., "The Analysis of Spatial Association by Use of Distance Statistics", Geogr. Anal., Vol. 24, No.03, 1992, pp. 189-206. 